\title{
Ernst Wendland
}

\section{THE LINGUISTIC, CONCEPTUAL, AND PRAGMATIC CHALLENGES OF COMMUNICATING GALATIANS 3:1-14 IN CHEWA}

\section{ABSTRACT}

The aim of this study is, first of all, to present a rhetorically oriented analysis of the central pericope of 3:1-14, with special reference to its pertinent oral-aural qualities. This forms the basis, in turn, for a comparative analysis of how this passage has been translated into Chewa in an old missionary-produced version (1922) in contrast to a more recent meaning-centered rendering (1998) as well as a special oral-poetic translation that was prepared as part of this study. Further attention is devoted to some of the conceptual challenges that this text, as an example of the Galatian epistle as a whole, poses for mother-tongue speakers due to their lack of an adequate biblical and hermeneutical frame of reference. Suggestions are offered as to how this significant cognitive disparity might be overcome through the use of a judicious selection of paratextual features, in particular, the incorporation of contextually relevant explanatory footnotes.

\section{1. "O FOOLISH GALATIANS ... !" - THE PROBLEM TO BE EXPLORED IN THIS STUDY}

Most Chewa speakers claim membership in one from among a great variety of Christian denominations. ${ }^{1}$ But how well do they comprehend their Scriptures - in particular, the oldest, most widely used vernacular translation that is available to them? Can one really blame a majority for being relatively "foolish" in terms of their comprehension of this popular, but rather difficult and out-of-date version? In my text-comparative study,

1 (Chi)Chewa is a major Bantu language spoken by some 12 million people in Malawi, Zambia, Mozambique, and Zimbabwe.

Ernst Wendland, Stellenbosch University, South Africa. E-mail address: erwendland@ gmail.com 
I begin by summarising the internal literary structure and principal oralrhetorical features of 3:1-14. This initial analytical overview indicates some of the major compositional challenges that translators must face, first of all, from the perspective of correctly understanding the biblical text, and then also as they endeavour to re-express the meaning of Paul's passionate discourse accurately and artistically in their language.

Next, I describe a sequence of the main difficulties that this pericope poses today for "ordinary" readers and hearers of a relatively literal local translation. This includes certain problems occasioned by an unnatural rendering of some of the key terms and concepts that Paul used, with reference now to a significantly disparate cognitive context, which he no doubt assumed that he held in common with his initial audience in Galatia. This exercise involves a selective evaluative review of the long-standing Buku Lopatulika ("Sacred Book") version ${ }^{2}$ in relation to the original Greek text, on the one hand, and the Buku Loyera ("Holy Book"), ${ }^{3}$ a more modern Chewa translation, on the other. My choice of items and issues for consideration in this section was guided by the provisional results derived from a number of individual questionnaires and group testing procedures. ${ }^{4}$

In the concluding portion of this study, I will supplement my argument for a revised, meaning-oriented (functional equivalent) rendering of this passage with several additional proposals that concern the text's perceived orality in the target language (TL), its visual printed format, and an accompanying paratext of supplementary contextualising resources. This study illustrates the fact that interlingual communication involves much more than merely rendering the ancient source text (ST) by using the corresponding verbal forms of some modern language. To ignore the larger levels of discourse organisation as well as the subtle, less evident aspects of Paul's persuasive, "poetic" strategy in translation is to leave contemporary readers/hearers rather limited ("foolish") with regard to their capacity for understanding the apostle's critical theological and rhetorical objectives.

2 Published by the Bible Society of Malawi (First edition, 1922).

3 Published by the Bible Society of Malawi (Blantyre, 1998).

4 Those whose opinions and evaluations were sought included seminary students of my first-year Romans exegesis class and the members of several local congregations in the Lusaka area. 


\section{THE POETIC, ORAL-RHETORICAL STRUCTURE OF 3:1-14}

Before one can make a comparative assessment of contemporary translations (to be carried out below), one must first carefully investigate the original text from which they are derived. This forms the basis in turn for my effort to re-express the impact and appeal of Paul's message in the Chewa language. I will not present a detailed linguistic, exegetical analysis of the passage at hand. But by employing the methodology used in several prior explorations of the New Testament epistles, ${ }^{5}$ I wish to evaluate this pericope from a somewhat different, but complementary standpoint - namely, from a discourse-oriented, literary-poetic and oral-rhetorical perspective. This is because, in keeping with virtually all formal compositions in the ancient world, so also the Galatian epistle was also not only orally composed, probably being set down permanently in writing by a scribe, but it was also prepared for oral-aural proclamation by a lector, or "performer" (Mitternacht 2007:58-59), before a listening audience. An ancient letter was thus the spoken embodiment of its author - a semiotically poorer, but none the less significant vocal substitute for the writer's personal presence and projected message. ${ }^{6}$

Furthermore, my studies suggest that this passage, like all of the other apostolic epistles, was not only rhetorically conceived, but it was also poetically constructed. In other words, as many scholars have pointed out, the text clearly reveals various types of persuasive speech (whether Semitic or Greco-Roman in nature) and, what is more, also a cadenced, linear style that exhibits repetition, balanced, paralleled expressions, and many different literary devices that feature the sense of sound. ${ }^{7}$ Space does not

5 Specifically, James, 1 John, Philemon, and 1 Peter in Wendland 2008. I am not arguing that 3:1-14 (or any other Pauline epistolary passage) exemplifies pure "poetry" in the Classical Greco-Roman sense - only that it appears to manifest an oratorical style of "poetic prose."

6 Furthermore, it may well be true that "Paul expected one of his co-workers ... to go and orally deliver the contents of the document in a rhetorically effective manner" (Witherington 2009:3).

7 I am not suggesting here that Paul composed this passage (and other epistolary texts) by consciously following the poetic forms of Hellenistic literature. Rather, my view is that he selectively employed his own rhetorical devices and rhythmic patterns (some also undoubtedly influenced by a Semitic style), both to effectively express the subject at hand and to render the text amenable to oral articulation, memorisation, as well as an auditory means of transmission and reception. It is interesting to note that current developments in Hellenistic poetic technique, i.e., a certain measure of phonological simplification, appear to support the type of discourse analysis that I have carried out: "From about 
permit a complete analysis of the oral-elocutionary structure of 3:1-14, but the following formatted diagram of the Greek text reveals a number of its primary poetic and phonic characteristics (cf. Wendland 2012:164-165). My overview of this pericope, which focuses upon the reiterated lexical items, is accompanied by selective footnotes that summarise and describe these elements along with their proposed thematic, rhetorical, and/or structural significance. Such qualities, too, need to be duplicated functionally in translation, if possible.

The sequence of measured lines on display below is simply my hypothetical reconstruction of the Greek text, including presumed paragraph units (separated by the broken underlines). Thus, I do not claim that the passage was necessarily composed with this specific literary arrangement consciously in mind, but only that it might have been conceived of in this way - to a greater or lesser extent. Form therefore expresses meaning also through the text's varied phonological features (including putative rhythmic breath spans). They serve both to shape this pericope structurally and to sharpen the thoughts and intentions of the author as he vicariously uttered them through a surrogate speaker as part of an emphatic corrective rebuke of his physically removed Galatian audience:

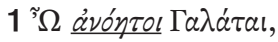

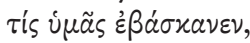

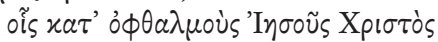

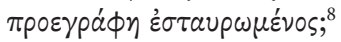

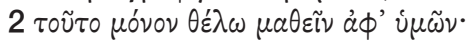

हैं है

$\ddot{\eta} \dot{\xi} \xi \dot{\alpha} \kappa 0 \tilde{\eta} \varsigma \pi i \sigma \tau \varepsilon \omega \varsigma ; 9$

the beginning of the Christian era, the distinction in colloquial Gr. speech between long and short vowel-quantities began to disappear, and the musical pitch-accent that had prevailed since archaic times began to be replaced by a tonic stress-accent similar to modern Gr. or Eng. ... [B]y the beginning of the 6th c. A.D., the characteristic Byzantine versification was well established, its guiding principle no longer syllable quantity but recurrent stress accent" (Herington 1993:487).

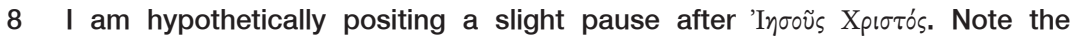
underlying consonance in $/ \varsigma /$ throughout this verse (after $\tau i \zeta$ ), a feature that subtly unites these initial, emotively expressive lines of direct address - the onset of Paul's principal argument sequence (Witherington 2009:126).

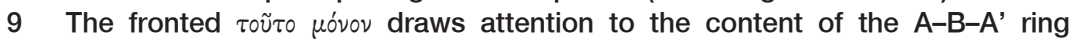

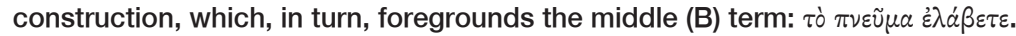
The two outer terms express a point-counterpoint sequence that moves from the lesser $(A)$ to the greater $\left(A^{\prime}\right)$. 


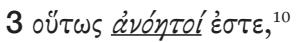

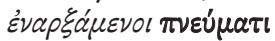

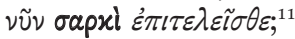

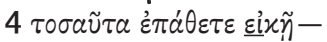

$\underline{\varepsilon l} \gamma \varepsilon x \underline{a} \underline{\underline{\varepsilon}} \underline{i} x \tilde{\eta} ;{ }^{12}$

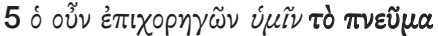

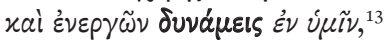

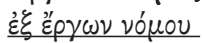

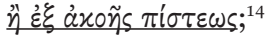

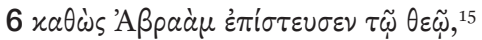

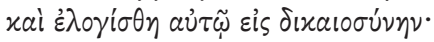

10 The reiterated ávóntoi (cf. 1a) occurs in a similar, emphatically fronted position.

11 A lexical chiasmus emphasises the antithetical concepts and demarcates the poetic lines. The middle term, the temporal adverb $v \tilde{v} v$, highlights the current precarious situation of many of the Galatian addressees - namely, àvóntoí, being in a "foolish" state of mind (cf. v. 1a).

12 The reiterated / $\varepsilon i /$ assonance draws attention to the negative concept "in vain," which throws into relief also the fronted demonstrative referent $\tau 0 \sigma \alpha \tilde{\tau} \tau \alpha$.

13 In this case, the lexical chiasmus reinforces complementary notions - but again involving a reference to the divine "Spirit" (i.e., $3 b$ and 5a).

14 The exact repetition of these contrastive thematic expressions: हैं हैp $p \omega \nu$ vónov

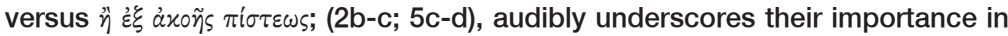
Paul's argument and structurally marks the close of the first paragraph (Paul's Rebuke).

15 The key concept of "faith-fulness/believe" continues from paragraph one at the onset of paragraph two, as Paul's scriptural exegesis of the Example of "Abraham" is introduced. This new, but related subject is also marked by the initial conjunction $x_{a} \theta \omega^{\prime}$ s $^{\prime} J u s t$ as/In the same way ...," which introduces a subordinate comparative clause (v. 6) that serves as a frame of reference for what follows (v. 7ff). The four evenly spaced occurrences of the central illustrative personage 'Aßpad́ (which also forms a unit-bounding inclusio) lend perceptible cohesion to this medial paragraph, as it alternates with the reiterated $\pi i \sigma \tau$ - stem (5x). According to Vaz, "With the use of $x a \theta \omega^{\prime} \omega_{\text {s, }}$ Paul seeks to answer his most important rhetorical question, and he summarises the answer by quoting Gen. 15:6, followed by the inference in 3:7 that it is by faith (implicitly contrasted with circumcision) that one becomes a child of Abraham" (Vaz 2011:75-76). Catchpole notes that "Gal 3:6-9 focuses on the experience of Abraham. That experience is the prototype of the experience described in vv. 1-5, for the word $\left.x a \theta \omega^{\prime}\right)_{s}$, with the Genesis 15:6 LXX citation attached, causes v. 6 to lean on what precedes. It is also an experience that anticipates what happens when the gospel is preached in the form of a promise and received by faith ..." (2006:381). It is indeed strange that Catchpole ends his study in v. 13, when this paragraph and pericope so clearly conclude in v. 14. 


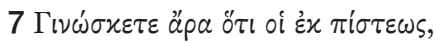

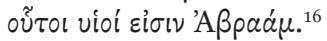

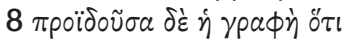

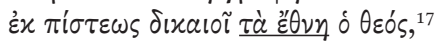

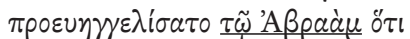

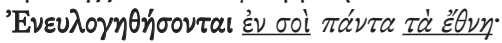

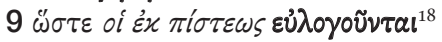

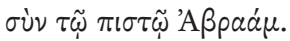

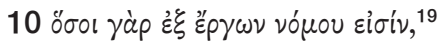

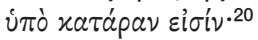

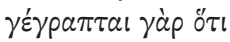

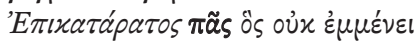

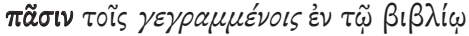

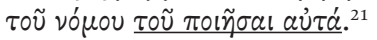

16 Assonance in -ol serves to stress the key phrases involved in this deictically

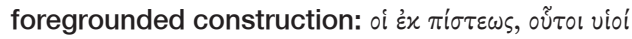

17 Here is another instance where Paul employs the word order (syntactic frontshifting) to spotlight the crucial notions that he is arguing for: $\dot{\varepsilon} \chi \pi i \sigma \tau \varepsilon \omega s \delta(x a 1 \circ i \tau \dot{\alpha}$ हैovin ò $\theta$ cós.

18 An elaborate interlocking double chiasmus in vv. 8-9 spotlights the prophetic personification of Scripture (v. 8) and conjoins all of the key concepts in this

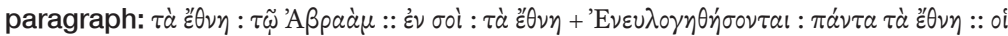

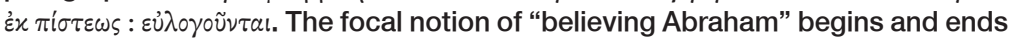

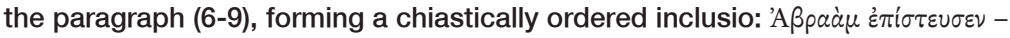
$\pi เ \sigma \tau \tilde{\omega}{ }^{~ ' A} \beta \rho \alpha a ́ \mu$.

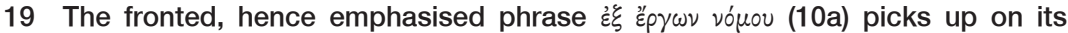
correspondent in v. $5 \mathrm{c}$ at the close of the first paragraph, thus forming an "exclusio" around the middle paragraph (vv. 6-9). Although the two topics of "works" and "law" lie in the presupposed background of paragraph 2, these terms are not explicitly mentioned. "Once the topic is switched from those of faith to those who are of works, the comment about their plight also contrasts with those in v. 9. The emphasis sharpens this contrast and reinforces the very different prospects facing these groups" (Runge 2010:280; on "emphasis" see ibid.:271-273).

20 Lexical repetition at the end of the first two lines (or clauses, हiбiv) helps to draw attention to what is different, namely, Paul's introduction of the negative and contrastive (i.e., with "blessing" in v. 9) notion of "cursing" ( becomes prominent $(5 x)$ in this third and concluding paragraph of the pericope.

21 'E

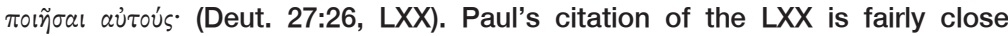

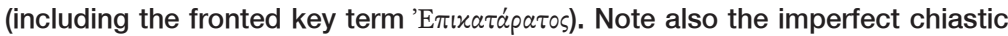

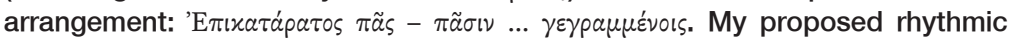




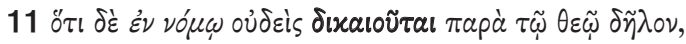

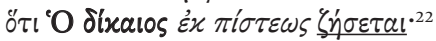

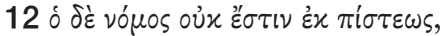

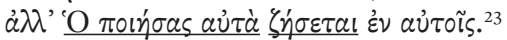

13 X

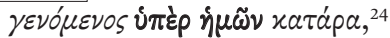

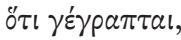

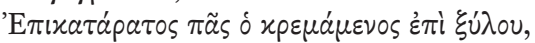

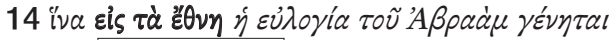

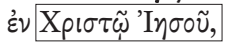

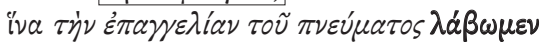

$\delta i \dot{\alpha} \tau \tilde{\eta} \varsigma \pi i ́ \sigma \tau \varepsilon \omega \varsigma^{25}$

Tolmie has proposed a credible chiastic arrangement for the entire pericope of $3: 1-14$, which I have slightly modified as follows: ${ }^{26}$

(not necessarily poetic!) lineation for this quotation is based primarily on sound correspondences and is thus more speculative than usual.

22 The (imperfect) chiasmus within the two clauses of v. 11 reinforces the

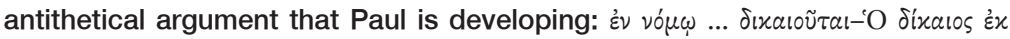
$\pi i \sigma \tau \varepsilon \omega \varsigma$. In addition, the back-shifted adjective $\delta \tilde{\eta} \lambda o v$ functions rhetorically as a qualifier of both ö $\tau \iota$ clauses.

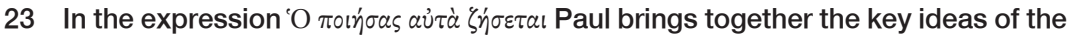
two preceding verses, i.e., 10 and $11 \mathrm{~b}$, with a clear emphasis on the notion of "doing". Thus, the only way to "live" by the "Law" is to "do it [all of its precepts]" - perfectly!

24 The impossibility of the preceding assertion is highlighted by another

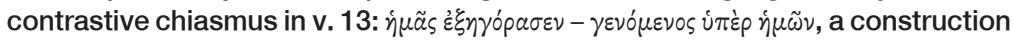
that stresses the pronoun "us". In addition, the central personal in the salvific

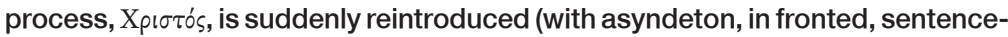
initial position; cf. 1c), further stressing Paul's point - and probably announcing the turning point of Paul's argument ( $C=>C^{\prime}$ in the chiasmus below).

25 The two final (iva) clauses that form the core of Paul's climactic summaryconclusion in v. 14 are chiastically worded in a way that draws attention to the radical theological notions that Paul is here bringing to the fore: $\varepsilon i \varsigma \tau \dot{\alpha}$ है $\theta v \eta$

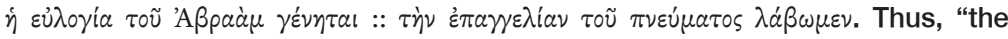
(God's) blessing of Abraham" is either equated with, and/or added to "the (God's) promise of the Spirit" - and "we" (all-inclusive!) are among those "nations" being referred to as the "recipients." How does it all happen? That is specified by the phrasal tags that are positioned at the end of each member of the chiasmus: $\dot{\varepsilon} \nu$ X order of the Christological title "Christ Jesus" (14b) is in chiastic arrangement with respect to its occurrence at the onset of this pericope in 1b. - perhaps thereby suggesting its use here as a unit-ending inclusio.

26 This arrangement is based generally on Tolmie (2005:123). I have added the inner " $D$ " elements - the central contrastive thematic focus; note also the 
A 1-5: You (Galatians) received the "Spirit [of God]" by "believing what you heard".

B 6-9: Abraham believed, was justified, and received the promise that believers from all "nations" would be "blessed" as he was.

C 10: All who try to keep the "Law" for salvation are "cursed"

D 11: Thematic contrast: no one is justified by the Law; only the righteous by faith will live.

D' 12: Thematic contrast: the Law is not of faith; only the one who keeps the Law (perfectly) will live.

C'13: Christ redeemed us from the "curse of the Law" by becoming a curse in our place.

B' 14a: He redeemed us so that the "blessing of Abraham" might come to [all] "nations" through [faith in] Christ - and ...

A' 14b: ... that "by faith" we [all] might receive the promise of the "Spirit [of God]".

In conclusion, the preceding analytical perspective on Paul's critical reprimand of his addressees in Gal. 3:1-14 clearly indicates that within the apostle's rhetorical repertory, sound too signifies sense. In other words, phonological features, such as rhythm, repetition, strategic phrasal positioning, word order, sound iteration, and euphony - all of these also contribute to the expression of his strongly affective, audience-engaging message. ${ }^{27}$ These acoustic devices serve, for example, to demarcate the discourse structure, to highlight important thematic correspondences or contrasts, and to render the text in a way that facilitates its oral enunciation as well as its memorisation for easier reference and recall. ${ }^{28}$ The implication

chiastic arrangement of thematic concepts in the parallel " $A$ " and "B" elements.

27 Many commentators consider Galatians to be an instance of "deliberative" rhetoric throughout, "the rhetoric of advice and consent, trying to get one course of action or another" (Witherington 2009:14, 126). But in Gal. 3:1-14 there would certainly seem to be at least a touch of "epideictic" rhetoric as well, the "rhetoric of praise and blame" (ibid.:14) - with Paul praising Father Abraham, but blaming the obstinate Galatians.

28 A twofold focus on aurality and mnemonic potential is also the subject of Mitternacht's detailed rhetorical and epistolary study of Galatians: "Focusing on aural reception, the task of this analysis is to take into account means of attracting attention, such as direct address, confrontational assertion and emotional appeal, and epistolary form and formulas that would have generated recollection and evoked an awareness of a basic progression of argumentation" (2007:58). We see a clear example of what Mitternacht terms "situational pertinence" (ibid.:59) throughout 3:1-5, as Paul resumes his sharp rebuke of 
for all Bible translators is substantial: If this phonic dimension was a functional aspect of the original intended meaning, then so it must also be taken into serious consideration when rendering this passage in another language. Paul's words must live on, not only in terms of their theological content, but also, in some way, also with respect to the vibrancy of the text's literary, including sonic ("oratorical"), qualities.

\section{HOW CLEAR IS PAUL'S COMPLAINT IN CHEWA?}

After carefully investigating the message of the ST in the source language (SL), including all of its structural, stylistic, and rhetorical features, translators must then attend to how best to convey the expressed meaning - formal, semantic, and pragmatic - in their mother-tongue, the TL. Space does not allow for a consideration of translation theory and practice here, ${ }^{29}$ but essentially, there are two basic points of reference: More or less literal with regard to the form of the ST, versus more or less liberal in terms of expressing its meaning in the target text (TT). This fundamental polarity results in two corresponding strategies of translation: "foreignisation," where one seeks to remain as close, or correspondent, as is practical to the SL forms in the TT, and "domestication," where one endeavours, to the extent possible, to reproduce the meaning of the ST in natural linguistic forms of the TL. As expressed in the well-known dictum of Schliermacher:

Either the translator leaves the author in peace ... and moves the reader towards him; or he leaves the reader in peace ... and moves the author towards him (Venuti 1995:19-20).

But what difference does it make? In the following exercise, I hope to demonstrate that a literal, "foreignised" approach to Bible translation does not communicate well when strictly applied in a Bantu language. As a case study, I will make assorted critical comments while working through the text of the Chewa equivalent of the venerable KJV, the Buku Lopatulika $(\mathrm{BL})$, which remains the preferred version in most Protestant liturgical and didactic settings. ${ }^{30}$ My observations are given in footnotes attached to a

the Galatians for their wavering faith (cf. 1:6-10). Foundational "formulaic" language then appears as Paul turns to well-known Scripture texts to support his pastoral reprimand and appeal for a resumption of Abrahamic faith (3:6-9) in contrast to a legalistic self-righteousness (3:10-14).

29 For a detailed orientation, see Wendland (2004:31-97).

30 This observation would apply to all four east-central African nations in which Chewa is spoken as a major language. Most Catholic readers, on the other hand, prefer to use the more modern and meaning-orientated Buku Loyera (Deuterocanonical) version. The old Buku Lopatulika is further hindered in 
relatively literal English back-translation of the $B L$ text. These often include reference to the new Chewa translation (NC) and concern: (a) the stylistic form of the translation, (b) its expressed content as perceived by ordinary reader-hearers, ${ }^{31}$ and (c) certain conceptual or contextual issues that are difficult to deal with in any translation standing alone. The BL Chewa text is formatted as published, line by line, but not including 19 harder to perceive hyphenated words, which arise from two narrow columns of small, rather dense justified print. There are no paragraph breaks throughout the 14 verses, and the text is inset only to distinguish the OT quotations in verses $10 \mathrm{~b}$ and $13 \mathrm{~b}$.

\begin{tabular}{|l|l|}
\hline \multicolumn{1}{|c|}{$\begin{array}{c}\text { Buku Lopatulika (BL) - } \\
1922 \text { version }\end{array}$} & \multicolumn{1}{c|}{$\begin{array}{c}\text { 'Sacred Book' - literal } \\
\text { back-translation }\end{array}$} \\
\hline $\begin{array}{l}\text { Agalatiya opusa inu, } \\
\text { anakulodzani ndani, }\end{array}$ & $\begin{array}{l}\text { 1 You foolish Galatians, who } \\
\text { ensorcelled you, }{ }^{32}\end{array}$ \\
\hline $\begin{array}{l}\text { inu amene Kristu anaonetsedwa } \\
\text { pamaso panu, wopacikidwa? }\end{array}$ & $\begin{array}{l}\text { you whom Christ was shown } \\
\text { before you, hung up (crucified)? } \text { ? }^{33}\end{array}$ \\
\hline
\end{tabular}

its communicability since it is a "missionary version," that is, a text that was composed in the main by non-mother-tongue speakers, which results in many unnatural lexical and grammatical choices (Wendland 1998:passim).

31 I am basing my critical observations in this section on: (a) my experience in working with Chewa Bible translators (and more recently study Bible editors) since the early 1970s; (b) teaching in the Chewa language using both the old and the new translations over the same period of time; (c) a written questionnaire for 13 first-year seminary students that assesses the clarity and comprehensibility of the Buku Lopatulika translation; and (d) personal directed queries of students and congregational members (in Chewa), to test specific wordings of this translation in comparison with the newer Buku Loyera version. Note that I originally worked this comparative chart out for all 14 verses of ch. 3 , but in the interest of space, only vv. 1-5 are reproduced below as a sample.

32 An expository footnote is necessary to explain the non-literal usage of "ensorcelled", which is a loaded term in the traditional religious belief system. The opening emotive vocative interjection is more dynamically expressed by a separate utterance, as in the new Chewa version (NC).

$33 \mathrm{BL}$ follows the Greek sentence structure, which results in a long unnatural interrogative in Chewa. The question raised is this: In which way was Christ "shown before you, crucified"? NC clarifies the sense: "When we preached Jesus Christ to you, we publicly showed him before you as someone crucified on a cross." 


\begin{tabular}{|l|l|}
\hline \multicolumn{1}{|c|}{$\begin{array}{c}\text { Buku Lopatulika (BL) - } \\
\text { 1922 version }\end{array}$} & \multicolumn{1}{c|}{$\begin{array}{c}\text { 'Sacred Book' - literal } \\
\text { back-translation }\end{array}$} \\
\hline $\begin{array}{l}\text { Ici cokha ndifuna kuphunzira } \\
\text { kwa inu, }\end{array}$ & $\begin{array}{l}\text { 2 This one thing I want to learn } \\
\text { from you/at your place, }\end{array}$ \\
\hline $\begin{array}{l}\text { Kodi munalandira Mzimuyo ndi } \\
\text { nchito za lamulo, }\end{array}$ & $\begin{array}{l}\text { Did you receive that Spirit with/ } \\
\text { by works of a law/command, }\end{array}$ \\
\hline $\begin{array}{l}\text { kapena ndi kumva kwa } \\
\text { cikhulupiriro? }\end{array}$ & or by/with hearing of faith ${ }^{36}$ \\
\hline Kodi muli opusa otere? & 3 Are you so foolish like that? ${ }^{37}$ \\
\hline $\begin{array}{l}\text { Popeza mudayamba ndi Mzimu, } \\
\text { kodi tsopano mutsiriza ndi thupi? }\end{array}$ & $\begin{array}{l}\text { Since you began with a Spirit, } \\
\text { now do you finish with a body? }{ }^{38}\end{array}$ \\
\hline $\begin{array}{l}\text { Kodi mudamva zowawa zambiri } \\
\text { zotere kwacabe? }\end{array}$ & $\begin{array}{l}\text { 4 Did you feel many such pains } \\
\text { for nothing? }{ }^{39}\end{array}$ \\
\hline ngatitu kwacabe? & if indeed for nothing? ${ }^{40}$ \\
\hline $\begin{array}{l}\text { Ndipo iye amene akuonjezerani } \\
\text { inu Mzimuyo, }\end{array}$ & $\begin{array}{l}\text { 5 And he who added unto you } \\
\text { that Spirit, }{ }^{41}\end{array}$ \\
\hline
\end{tabular}

34 Paul wants to "query" the Galatians (NC), not to "learn" anything from them

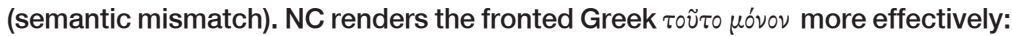
"I ask you just this one thing:"

35 "That Spirit" requires a clearer reference - the "Holy Spirit" (NC). "Works of a law" becomes "by following (i.e., obeying) Laws" in NC.

36 "Hearing of faith" is literal Greek and unintelligible to virtually all contemporary respondents (see Tolmie 2005:105-106 for the various exegetical options for áxoñ $\left.\pi^{i} \sigma \tau \varepsilon \omega \varsigma\right)$. NC proposes an interesting combination of form and meaning: "by hearing and believing the Good Message (Gospel)".

37 This is worded as a real question in BL - an insult! NC marks the question as being rhetorical.

38 As expressed in $\mathrm{BL}$, this query could be mistakenly interpreted as a reference to the Galatians' involvement with witchcraft - the African kind! NC: "Do you want to (try and) extend what the Holy Spirit began to do among you to the limit by means of your own powers?"

39 It is not at all clear what "such pains" designates. NC refers "receiving all those things" to what the Holy Spirit had done among them (vv. 2-3, GNT).

40 This final phrase has no meaning at all for hearers. NC: "I do not believe that it was all in vain."

41 The referent for "he" is unclear, as is the expression "added unto", which is apparently an attempt to literally render the Greek ह่ $\pi\llcorner\propto p \eta \gamma \tilde{\omega} \nu$. NC: "Has God, who gave you the Holy Spirit ..." 


\begin{tabular}{|l|l|}
\hline \multicolumn{1}{|c|}{$\begin{array}{c}\text { Buku Lopatulika (BL) - } \\
1922 \text { version }\end{array}$} & \multicolumn{1}{c|}{$\begin{array}{c}\text { 'Sacred Book' - literal } \\
\text { back-translation }\end{array}$} \\
\hline nacita zimphamvu mwa inu, & and did powerful things in you, ${ }^{42}$ \\
\hline atero kodi ndi nchito za lamulo, & $\begin{array}{l}\text { did he do such with/by works of } \\
\text { a law, }{ }^{43}\end{array}$ \\
\hline $\begin{array}{l}\text { kapena ndi kumva kwa } \\
\text { cikhulupiriro? }\end{array}$ & or by/with hearing of faith? ${ }^{44}$ \\
\hline
\end{tabular}

As the preceding comparative review would suggest, the $B L$ version is quite difficult to comprehend for most "ordinary" readers (those not theologically trained). My research also indicates that this translation presents some significant problems of intelligibility for many pastors and seminary students as well, especially those who are simply hearing the text with no advance preparation. The New Chewa (NC) version helps considerably in this regard - that is, in terms of naturalness of expression and clarity of content. However, even in the case of this more meaningful version, certain difficulties do remain, namely, those that pertain to the cognitive context necessary for interpreting the biblical text in view of its ancient cultural and socioreligious setting.

\section{CONTEXTUALISING THE GALATIAN EPISTLE FOR CONTEMPORARY RESPONDENTS}

It is possible to "fix" a relatively literal, uncommunicative translation by replacing - or complementing - it with a more meaning-based version, as has been shown in the preceding section. In fact, it is important to point out that the Buku Lopatulika is not a bad translation, and the Buku Loyera is by no means a perfect one. The older version was probably the best that could be done a century ago, under the prevailing circumstances of production at that time; on the other hand, the recent "popular language" version can certainly be improved in a number of areas. However, even the best translation cannot communicate effectively if the intended audience (readership) does not have sufficient cognitive background to fully understand the main ideas that the original author wished to convey

42 NC eliminates the ambiguity of the literal BL ( $\dot{\varepsilon} \nu \tilde{\mu} \mu \nu)$ by saying "in your midst".

43 NC uses the clarified renderings from v. 2 and also streamlines the syntax of this long question.

44 NC (wrongly this time!) interprets $x a \theta \omega$ s s as a concluding subordinate conjunction, and hence ends the first paragraph at the end of v. 6 instead of v. 5 (as analysed above). 
to his initial receptors in their Ancient Near Eastern setting. The potential problems - "conceptual mismatches" - that may arise under these conditions are summarised on the following diagram, which indicates four different hermeneutical possibilities regarding some "key concept" or expression in the source (biblical) text: ${ }^{45}$

\begin{tabular}{|c|c|c|}
\hline $\begin{array}{c}\text { PERCEPTION } \rightarrow \\
\text { REALITY } \downarrow\end{array}$ & $\begin{array}{c}\text { Hearers think that } \\
\text { they SHARE this } \\
\text { concept }\end{array}$ & $\begin{array}{l}\text { Hearers do NOT } \\
\text { think they share } \\
\text { this concept }\end{array}$ \\
\hline $\begin{array}{l}\text { The concept IS SHARED } \\
\text { between the Source and } \\
\text { Target settings }\end{array}$ & $\begin{array}{l}\text { 1. The intended } \\
\text { SL concept is well } \\
\text { communicated, e.g., } \\
\text { "the gentiles" (v. 8). }\end{array}$ & $\begin{array}{l}\text { 2. The intended } \\
\text { concept is simply } \\
\text { unrecognised in the } \\
T T, \text { e.g., "a tree" (v. } \\
\text { 13). }\end{array}$ \\
\hline $\begin{array}{l}\text { The concept IS NOT } \\
\text { CLOSELY SHARED } \\
\text { between the Source and } \\
\text { Target settings }\end{array}$ & $\begin{array}{l}\text { 3. An unintended } \\
\text { concept is wrongly } \\
\text { communicated in the } \\
T T, \text { e.g., "the Spirit" } \\
\text { (v. 2); "cursed" (v. 13). }\end{array}$ & $\begin{array}{l}\text { 4. The intended SL } \\
\text { concept is completely } \\
\text { unknown, e.g., "the } \\
\text { Scripture foresaw" } \\
\text { (v. 8). }\end{array}$ \\
\hline
\end{tabular}

To explain: An important concept in category 1,46 such as "the gentiles" ( $\left.\tau \dot{\alpha} \varepsilon^{\prime \prime} \theta \nu \eta, v .8\right)$, is not very difficult to convey, provided that it is rendered correctly in the TT. In this case, NC's "people of other tribes" is a clearer expression than BL's "those-of-tribes/types" (one word), which is lexically ambiguous in this context, for it could also be understood as "those [people] of [various] kinds," for example, with respect to a different personality or character. Similarly, the items in category 2 can be handled quite readily through a good translation technique. In the case of a "tree" ( $\xi \dot{\nu} \lambda \circ u)$ in v. 13, for example, uninitiated (biblically illiterate) respondents generally wonder, Well, what kind of a tree? Or, why and in what way was Christ "hung" on that tree? But in this case the term used to render "crucify" ( $\sigma \tau a u p o ́ \omega)$ in Chewa (both translations) has traditionally been the verb meaning "hang something up/suspend" (-pachika), so this leads most people to a correct perception of the metonymic usage of "tree" in v. 13.

The concepts in the bottom two boxes tend to cause the most difficulty for translators and their primary audience alike - in the case of category 3 , because people think they understand the vernacular text, when in reality

45 Adapted from Hill, et al. (2011:170).

46 This would be a concept that is conceptually "shared" between the Source and the Target settings - and one that ordinary hearers/readers think or assume that they do actually have in common, like "gentiles". 
they do not. In the case of category 4 , it is because they simply do not comprehend, period, especially when confronted with a literal translation. The need for careful testing concerns the class 3 expressions in particular since translators often simply assume that their readers (hearers) understand the TT because it happens to be worded well in their language. The word for "spirit" ( $\tau \dot{0} \pi \nu \varepsilon \tilde{u} \mu \alpha$, v. 2), for example, is one of the most difficult category 3 notions to deal with (Wendland 1998:135-138). ${ }^{47}$ The commonly used Chewa noun mzimu (both BL and NC) refers to an "ancestral spirit," thus implying some human being who died and now manifests his/her presence periodically for weal or woe as one of the "living dead"! Naturally, it has required a great deal of church teaching to sort out that rather large conceptual mismatch. The NC at least attempts to signal the correct sense by always adding the qualifier "holy" (Woyera - literally "White"). Finally, in the case of concepts in category 4 , translators have to be the most creative and resourceful. For example, the personified expression "the

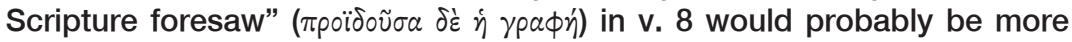
understandably rendered as "the Writings spoke ahead of time" (Malembo adaneneratu).

But as suggested above, most translation project organisers today realise that their TL text needs to be supplemented by a diverse array of paratextual helps, such as section headings (sometimes introductory summaries too), extensive cross references, glossary entries for recurrent key terms or technical vocabulary, illustrations, charts, diagrams, maps, and - of greatest importance-pertinent explanatory-descriptive notes. The last-mentioned are essential for contextualising the biblical text on behalf of a specific audience group and level of readership (or biblical "literacy"). These comments create at least a minimal cognitive context to enable the users of a translation to bridge the great conceptual divide that so often (and frequently unnoticed) separates them from the biblical world - its history, politics, religion (even some crucial scriptural notions), customs and culture, flora and fauna, geography and topography, and so forth. Also needed are notes that call attention to significant instances of the manifold biblical intertextuality, for example, the references to Deut. 27:26, Hab. 2:4, Lev. 18:5, and Deut. 21:23, which form the indispensable legal backdrop for Paul's argument in the paragraph covering Gal. 3:10-14.

47 This concerns the issue of implicit information at the "world view" level, about as deep as we can get in terms of a conceptual communicative clash. Matthews et al. posit a still deeper cognitive level, namely, the "image schema stratum," which is "based on sensorimotor actions that are common to the human body" (2011:32). However, this would seem to be also encompassed by, or incorporated within their "worldview stratum" (ibid.:31). 
Below I will briefly illustrate the possible benefits of such contextual supplementation by giving three examples of footnotes (in back-translation) from the new Chewa Study Bible - New Testament, which is currently in press. ${ }^{48}$ Each of these comments is keyed to verse one alone. First of all, some clarification is needed to explain Paul's harsh use of language, apparently all of a sudden, at the very beginning of this pericope:

You foolish Galatians: The word "foolish" in Greek means a person who lacks common sense, having poor character, who cannot restrain himself from doing evil, a person of unstable thinking, unable to clearly distinguish between good and bad (Lk. 24:25; Rom. 1:14; 1 Tim. 6:9, Tit. 3:3). Paul does not mean a person with diminished reasoning capacity, but instead, someone who fails to use his/her power to remain alert and is unable to quickly discern erroneous matters. These words remind us of how Paul began this letter in 1:6-9.

The second example attempts to explain a rather sensitive expression that relates to the ancient Chewa belief system:

Who has ensorcelled you?: Without a doubt, the ones who had practiced sorcery against them were those false teachers. The believers at Galatia were taken up with the doctrine that they were teaching, so much so that it was as if someone had cast a spell on them. ${ }^{49}$

However, due to the great probability of misunderstanding here, a somewhat fuller explanation is needed, for example (continuing from the preceding):

So the Apostle Paul was not accusing these enemies of actually practicing sorcery. Rather, he was accusing them with confusing

48 With the Bible Society of Malawi (Blantyre); the target date for publication was late 2012, but the lack of sufficient funding has delayed this to date (February 2014).

49 In Chewa, as in many Bantu language-cultures, one must distinguish between "sorcery," to cast an evil spell on, or use magic against someone in order to harm him/her for personal gain, and "witchcraft" proper, which refers to a mystical kind of necromancy and/or necrophagy that is practiced nocturnally in order to sustain one's supernatural power to carry out or participate in certain illicit, antisocial activities. Here we have another significant cognitive mismatch at the worldview level. Consequently, the bare translation can "give rise to different explicatures ... [and] these explicatures have different affective results" for the audience (Matthews, Rountree \& Nicolle 2011:41). Thus, the practice of sorcery, if discovered (e.g., by divination), calls for compensation, whereas "witchcraft" requires personal and social rehabilitation through various ritual practices. 
the thinking of the Galatians and hence leading them astray, away from the true teaching about Christ.

Finally, an explanation that pertains to Paul's theology and pastoral practice is accompanied by a biblical analogy that might be useful in preaching or teaching:

We manifested him publicly in your presence as one crucified on the cross: Refer to 1 Corinthians 1:23; 2:2. The words "we manifested him publicly" mean that during his preaching Paul most vividly displayed Jesus so that everyone was able, in their hearts, to visualize him as being crucified. Compare this with the serpent that Moses lifted up on a tree (Num. 21:9). ${ }^{50}$

Contextualised notes of this nature make it possible for contemporary Berean believers (Ac. 17:11) - keen Bible readers - not only to better relate the translated text of Scripture to its original setting and meaning, but also to apply it more precisely and perceptively to their present way of life, mental frame of reference (world-view, value system, etc.), and current sociocultural circumstances.

\section{SHAPING A TRANSLATION FOR ORAL-AURAL ARTICULATION}

I have already mentioned the importance of the sonic dimension of the biblical text with respect to both interpretation and also its expression in translation via various media of communication. This would include the normal mode of some kind of printed publication as well as many types of non-print media, e.g., audio (radio, CD, even tape cassette), audio-visual (DVD, video, TV), electronic (including cell phones), internet websites (which incorporate visual printed text), and several dramatic performative formats (traditional as well as modern theatrical and musical productions). The last-mentioned - music and song - is especially important in many parts of Africa, where a tradition of public oral performance is still being

50 In this connection, namely, "crucifixion," I might point out another contextual note that is urgently needed near the end of this pericope, in v. 13. This involves the concept of "curse" and "cursing," where we again have a serious cognitive clash at the worldview level. Due to its importance as a biblical key term, especially in the Old Testament (e.g., Deut. 21:23), the literal Chewa equivalent (-temberera) is retained in translation. However, its figurative meaning needs to be pointed out, for example: "To be cursed is not to be harmed by someone's evil speech, but it means to be condemned - to be judged guilty and liable to punishment by God." 
maintained (folktales, riddles, proverbs, laments, lullabies, etc.), perhaps coupled with a modern medium of transmission such as radio or television. In the case of most of these methods of communication, a translated text that has been specifically fashioned for oral-aural presentation is desirable, in some cases essential.

But how can such a cadenced, sound-sensitive version be prepared? One can do no better than to use the original text of Scripture as a model in this regard. As was suggested in section 3 above, the pericope of Gal. 3:1-14 gives a strong indication of having been composed in a rhetorically structured manner as "poetic prose" - not pure poetry, but then again, not ordinary unembellished prose either. I have argued that a case can be made for asserting that this passage has not only been orally expressed during its composition - that is, aloud to Paul's scribe or amanuensis -but it has also been constructed in a way which enhances its public oral articulation and aural reception, as well as its potential for memorisation and future recall. Therefore, the same sort of phonic-poetic technique might be employed in order to create a rhythmic and euphonious translated text that functions in a corresponding manner. ${ }^{51}$

The following is my attempt to mould a revised version of the NC translation to serve this purpose. It is a text that has also been formatted on the printed page in a way that would facilitate its legibility and hence also its potential for oral expression. Only the first five verses have been reproduced below as an illustration for critique.

\section{Chikhulupiriro chokha chimapatsa moyo}

1 Agalatiya opusa inu, adakulodzani ndani?!

Pamene tidalalikira za Yesu Khristu kwa inu, tidamuwonetsa poyera pamaso panutu ngati wopachikidwa pa mtanda ndithu.

2 Tsono chinthu chimodzi chokha ndikufunseni:

Kodi inu mudalandira Mzimu Woyera uja

pakutsata Malamulo, kapena kunena zoona, pakumva n'kukhulupirira Uthenga Wabwino?

3 Kani ndinu anthu opusa chotere?!

Kodi zimene Woyerayo adayamba kuchita mwa inu, mukufuna tsopano kuzifikitsa pake penipeni

51 See Wendland (2008:132-142); the Chewa poetic genre modelled here (ndakatulo) does encompass indigenous "rhetorical criticism" as well as topics of an expository nature. Not every translation team would be capable of composing such an "oratorical" version, but where the circumstances allow (e.g., the intended audience group, setting, and medium), it might be considered as a translational option. 


\section{pogwiritsa mphamvu zanuzanutu?}

4 Kodi mudasaukira zonse zija pachabe?

Ai, sindikukhulupirira kuti m'pachabe!

5 Mulungu ndiyedi adakupatsani Mzimu Woyera, ndipo pakati panu adachita zambiri zozizwitsa.

Nanga zimenezi ankachita chifukwa mumatsata Malamulo, kapena chifukwa mudamva n'kukhulupirira Uthengawo ${ }^{52}$

This special poetic rendition illustrates the following oral-rhetorical features (some of which are emphasised above through the use of underlining, boldface, and italics):

- Balanced, rhythmic utterances,

- Frequent line-end rhymes or reduplication,

- General and concentrated euphony of expression,

- Word order shifts (such as fronting) for focus and emphasis,

- Use of deictic particles, independent pronominals, and intensifiers,

- Attitudinally marked rhetorical questions, as in the original text, and

- Additional idiomatic wordings.

The following is a relatively literal back-translation into English:

Faith alone gives life

1 You foolish Galatians, who has ensorcelled you?!

When we preached about Jesus Christ to you, we clearly manifested him before your eyes like someone hung up (crucified) on the cross for sure.

2 So just one thing l'm asking you:

Did you receive the Holy Spirit

by observing the Laws, or to speak the truth, by hearing and believing the Good News?

3 Could it be that you are so foolish like that?!

Say, the things which the Holy One began to perform among you, do you now wish to bring them to a climax

by employing your very own powers?

52 In v. 5 the Chewa version does not reproduce the repetition of the Greek text exactly; a slightly different grammatical construction was used in order to foreground the key antithetical concepts - "observing the Law" versus "hearing and believing the gospel." 
4 Say, did you suffer all those things for nothing?

No, I don't believe that it was for nothing!

5 God is the one who gave you the Holy Spirit, and in your very midst he did many amazing things.

So now, did he do all these things because you observe Laws, or because you heard n'believe that (Good) News?

\section{CONCLUSION: COMMUNICATION, CONTEXT AND COGNITION}

Translation is a highly specialised form of verbal communication. It is a very complicated way to send messages because two different languages - semiotic signaling systems - are involved. Furthermore, two, often highly disparate cognitive reference networks (mental models) are activated by the respective lexical signals in each language as used in its particular cultural context. With regard to Bible translation, the process is made even more difficult due to the great time gap and information differential between the two dissimilar communicative settings, ancient and modern..$^{53}$ In some cases then, we cannot be sure about what exactly the original writer intended to convey by a certain word, phrase, clause, or even a complete sentence. For example, the commentaries and versions differ in their interpretation of the verb $\varepsilon^{\pi} \dot{\alpha}^{\prime} \theta \varepsilon \tau \varepsilon$ in Gal. 3:4: Does it mean "suffered" with reference to prior persecutions that the Galatians had gone through (e.g., NIV, NET), ${ }^{54}$ or does it refer instead to their prior beneficial spiritual "experiences" (e.g., GNT, CEV)? ${ }^{55}$

Fortunately, such sharply contrasting conceptual scenarios evoked by the same original text are relatively few and far between. However, as was suggested in the little Chewa case study earlier, a notable cognitive lack of correspondence remains for most contemporary readers - and textually "blind" hearers in particular - a situation that frequently leaves them rather "foolish" with respect to their understanding of the Scriptures. A selection

53 " [T] he true nature of interlingual translation [is] a social and cultural process that can only be understood in wider cognitive contexts of the creation and transformation of meaning in and across cultural boundaries" (De Vries 2011:82).

54 For example, Bruce (1982:150); Keener (1993:525).

55 For example, Martyn (1998:285); Longenecker (1990:104). The context of Paul's argument at this point would seem to favor this interpretation, although earlier references or allusions to "persecution" in the letter (e.g., 1, 4, 13, 23) make the former construal also possible. Thus, this may be an instance of "semantic density," where both senses fit the textual setting and may well have been intended by the author (Wendland 1990). 
of "damage control measures" must therefore be put into effect to limit or to compensate for any lack or loss of information that is (not) conveyed by a modern translation. As already suggested, various paratextual devices can be put into play (illustrations, summary introductions, explanatory notes, etc.) in order to create a more accurate and extensive mental framework for interpreting the biblical text, one that is contextually conditioned to serve a particular target constituency. ${ }^{56}$

In this study, however, I have also had occasion to draw attention to yet another, less familiar semiotic dimension of the Scriptures, one that is not often addressed in the various translations which are available today. That is the literary (poetic) aspect of the original, which includes its special appeal to sound - to oratory - as well as a persuasive verbal style that has the capacity and quality to evoke important emotive and esthetic feelings within a source-language-sensitive audience..$^{57}$ By this I mean a group of listeners who are aware of what is going on, not only linguistically, but also rhetorically and artistically in the Greek (or Hebrew) text. ${ }^{58}$ In contrast, those Bible consumers today who must access its messages via a relatively literal vernacular version may be led to "foolishly" (i.e., wrongly - in the absence of sufficient insight, experience, or evidence) conclude that the original documents of Scripture were composed in an equally awkward, difficult, unsophisticated, and/or inelegant manner.

This complex esthetic-affective factor is a much more challenging issue for translators to deal with because it requires significantly more resources to be expended in terms of time, financing, and-most of all - compositional talent. In this crucial respect too, it would seem, creatively artistic translators are born, not made. The point is, such capable individuals are indeed usually present - somewhere - in any language community, most certainly here in Africa. The problem is first to discover such wordsmiths and then proceed to convince them of the vital need to contribute their particular spiritual gift to the worldwide cause of communicating the same

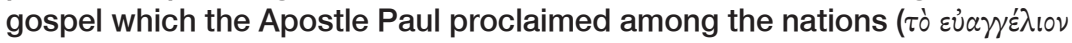

56 "The intent is to enhance the concept of Bible translation from merely the transfer of meaning or communication of information - processes that commonly consider only the surface structure of culture - to one that accesses cultural deep structure such as values, value orientations and worldview. These cultural components are important, and at times critically important to the manner in which the receptor audience will interpret the Scriptures" (Matthews et al. 2011:45).

57 See the various essays in Maxey and Wendland (2012).

58 This is the major thrust of my argument in Translating the Literature of Scripture (2004). 


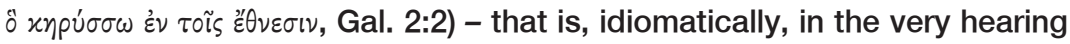
of their own people (cf. Acts 2:11).

\section{BIBLIOGRAPHY}

BRUCE, F.F.

1982. The Epistle to the Galatians. Grand Rapids: Eerdmans. NIGTC.

Catchpole, D.

2006. Galatians 3:10-13: Crucifixion, curse, and resurrection freedom. In: D.L. Bock \& B.M. Fanning (eds.), Interpreting the New Testament text: Introduction to the Art and Science of Exegesis (Wheaton: Crossway), pp. 377-385.

Cosby, M.R.

2002. Galatians: Red-Hot rhetoric. In: A. Eriksson, T.H. Olbricht, \& W. Uebelacher (eds.), Rhetorical argumentation in Biblical texts (Harrisburg: Trinity, ESEC 8) pp. 296-309.

DE VRIES, L. J.

2011. Linguistics as translation. Translation (Inaugural Issue): pp. 79-82.

DuNN, J.D.G.

1983. The Epistle to the Galatians. Peabody: Hendrickson. BNTC.

Herington, C.J.

1993. Greek poetry - The Hellenistic age. In: A. Preminger \& T. Brogan (eds.), The New Princeton encyclopedia of poetry and poetics (Princeton: Princeton University Press) pp. 486-488.

Hietanen, M.

2007. The argumentation in Galatians. In: D.F. Tolmie (ed.), Exploring new rhetorical approaches to Galatians (Bloemfontein: UFS, Acta Theologica Sup 9), pp. 99-120.

Hill, H., Gutt, E-A., Hill, M., Unger, C. \& Floyd, R.

2011. Bible Translation basics: Communicating Scripture in a relevant way. Dallas: SIL International.

KeEneR, C.S.

1993. The IVP Bible background commentary - New Testament. Downers Grove: InterVarsity.

LONGENECKER, R.N.

1990. Galatians. Dallas: Word. WBC 41.

MARTYN, J.L.

1998. Galatians: A new translation with introduction and commentary. New York: Doubleday. AB 33A. 
Matthews, T.G., Rountree, C. \& Nicolle, S.

2011. Implicit aspects of culture in source and target language contexts. Journal of Translation 7(1): 21-48.

MitTERnACHT. D.

2007. A structure of persuasion in Galatians: Epistolary and rhetorical appeal in an aural setting. In: D.F. Tolmie (ed.), Exploring new rhetorical approaches to Galatians (Bloemfontein: UFS, Acta Theologica Sup 9), pp. 53-98.

MaXeY, J. \& Wendland, E.R. (Eds.)

2012. Translating sound and performance of the Bible. Eugene: Cascade Books. Biblical Performance Criticism.

RUNGE, S.E.

2010. Discourse grammar of the Greek New Testament. Peabody: Hendrickson.

THUREN, L.

1999. Was Paul angry? Derhetorizing Galatians. In: S.E. Porter \& D.L. Stamps (eds.), The rhetorical interpretation of Scripture: Essays from the 1996 Malibu conference (Sheffield: Sheffield Academic Press), pp. 302-320.

Tolmie, D.F.

2005. Persuading the Galatians: A text-centred rhetorical analysis of a Pauline letter. Tubingen: Mohr Siebeck. WUNT 190.

$\mathrm{VAZ}, \mathrm{C} . \mathrm{A}$.

2011. Functionally equivalent translation of New Testament hortatory discourse into Hill Madia. Ph.D. Dissertation, Fuller Theological Seminary, School of Intercultural Studies.

VenUtI, L.

1995. The translator's invisibility: A history of translation. London: Routledge.

WENDLAND, E.R.

1990. What is truth? Semantic density and the language of the Johannine Epistles. Neotestamentica 24(2): 301-333.

1998. Buku Loyera: An introduction to the New Chichewa Bible translation. Blantyre: CLAIM.

2004. Translating the literature of Scripture. Dallas: SIL International.

2008. Finding and translating the oral-aural elements in written language: The case of the New Testament Epistles. Lewiston \& Lampeter: Edwin Mellen Press.

2012. Comparative rhetorical poetics, orality, and Bible translation. In Maxey \& Wendland, q.v., pp. 139-178.

Witherington III, B.

2009. New Testament rhetoric: An introductory guide to the art of persuasion in and of the New Testament. Eugene: Cascade Books. 
Wendland

Keywords

Gal. 3:1-14

Linguistic

Chewa

Literary analysis

Bible translation
Communicating Galatians 3:1-14 in Chewa

Sleute/woorde

Gal. 3:1-14

Linguïsties

Chewa

Literêre analise

Bybel vertaling 